\title{
POTENSI SILASE KULIT JAGUNG SEBAGAI BAHAN PAKAN FERMENTASI
}

\author{
Rahmiwati Hilma, Agustina Wulandari, Wahyuningsih
}

Fakultas MIPA dan Kesehatan, Universitas Muhammadiyah Riau Jln. Tuanku Tambusai Ujung No. 1 Pekanbaru 28285

UPT Pengujian dan Sertifikasi Mutu Barang Disdagkop UKM Provinsi Riau e-mail: rahmiwatihilma@umri.ac.id

\begin{abstract}
ABSTRAK
Sumber daya perikanan darat saat ini sangat menjanjikan untuk mencukupi kebutuhan nasional akan bahan pangan berbasis protein tinggi. Pakan merupakan salah satu unsur penting dalam kegiatan budidaya yang menunjang pertumbuhan dan kelangsungan hidup ikan budidaya. Mahalnya harga pakan dapat diatasi salah satunya dengan membuat pakan buatan sendiri menggunakan metode yang sederhana dengan memanfaatkan sumber-sumber bahan baku yang murah, mudah didapat, mudah diolah dan mengandung zat gizi yang diperlukan. Pada pembuatan pakan diharapkan menghasilkan pakan yang memiliki kandungan gizi yang tinggi, salah satu caranya adalah dengan fermentasi. Pembuatan pakan ikan fermentasi pada penelitian ini diawali dengan pembuatan silase kulit jagung menggunakan probiotik ikan yang telah diaktifasi menggunakan molase dan dilanjutkan dengan pencampuran silase kulit jagung dengan batang pisang, kotoran kambing, dedak padi, abu sekam dan probiotik ikan yang telah diaktifasi dengan 3 variasi komposisi (pakan A, B, C) dan difermentasi selama 28 hari. Data yang diperoleh dianalisis secara statistic menggunakanan alisis Rancangan Acak Lengkap (RAL) dan perbedaan antara perlakuan diuji dengan uji Tukey. Analisisuji $\mathrm{F}$ pada variasi 3 komposisi menunjukkan perbedaan yang nyata $(\mathrm{P}<0,05)$ terhadap kadar air, abu, protein, lemak, serat dan karbohidrat. Pakan C fermentasi merupakan komposisi terbaik dengan kadar air 78,36 \pm $78,36 \%$, kadar abu $10,69 \pm 0,06 \%$, kadar protein $4,15 \pm 0,05 \%$, kadar lemak $0,56 \pm 0,01 \%$, kadar serat 3,03 $\pm 0,01$ $\%$ dan kadar karbohidrat $3,30 \pm 0,00 \%$.
\end{abstract}

Kata kunci: fermentasi, kulitjagung, pakan, probiotik, silase

\section{PENDAHULUAN}

Sumber daya perikanan darat saat ini sangat menjanjikan untuk mencukupi kebutuhan nasional akan bahan pangan berbasis protein tinggi. Pakan merupakan salah satu unsur penting dalam kegiatan budidaya yang menunjang pertumbuhan dan kelangsungan hidup ikan budidaya. Pakan pada kegiatan budidaya umumnya adalah pakan komersial yang menghabiskan sekitar $60-70 \%$ dari total biaya produksi. Umumnya harga pakan ikan yang terdapat di pasaran relatif mahal. Hal inilah yang menyebabkan pentingnya pakan sehingga perlu dilakukan penelitian untuk memperbaiki nilai nutrisi pakan yaitu dengan proses pengawetan seperti silase (Faharuddin, 2014) dan penambahan probiotik melalui proses fermentasi (Arief, et al., 2014).

Bahan alternatif yang murah dan mudah didapat salah satunya adalah limbah organik. Berdasarkan teknologi yang sudah ada, pengkayaan bahan pakan berasal dari limbah dengan memanfaatkan bahan kimia maupun secara mikrobiologi secara tidak langsung dapat digunakan sebagai bahan pakan hewan (Wiyatno at al.,, 2010).

Limbah jagung berupa kulit jagung atau klobot jagung sampai saat ini pemanfaatannya masih kurang maksimal, padahal jumlahnya sangat melimpah ruah. Jika dibakar menimbulkan pencemaran udara, jika dibuang ke sungai menyebabkan banjir, tumpukannya bisa menyebabkan sarang penyakit. Kulit jagung mengandung gula yang cukup banyak sehingga sangat potensial untuk dijadikan silase karena kadar gulanya cukup tinggi (Anggraeny et al., 2005; 2006).

Pada pembuatan pakan diharapkan menghasilkan pakan yang memiliki kandungan gizi yang tinggi. Salah satu caranya adalah dengan fermentasi. Salah satu mikroorganisme yang sering digunakan dalam proses fermentasi adalah probiotik ikan yang merupakan spesies umum yang banyak digunakan dalam fermentasi 
pakan. Proses fermentasi dapat meningkatkan kadar protein, menurunkan kadar serat kasar dan menurunkan kadar HCN yang terdapat pada kulit singkong (Pratiwi, 2015). Pada penelitian sebelumnya Setyono. H. (2007) melakukan fermentasi pada pakan ternak dengan jerami padi sebagai substrat menggunakan probiotik ikan selama 14 hari, dilanjutkan penambahan probiotiknya pada hari ke-15 dan difermentasi lagi sampai 28 hari. Dari hasil didapatkannya peningkatan kandungan protein dan penurunan kandungan serat kasar.

Tujuan Penelitian dari penelitian ini adalah:

1. Mengetahui bahwa pengolahan limbah kulit jagung, dan limbah organik lainnya (dedak padi, abu sekam, batang pisang, pupuk kandang kambing) dan probiotik ikan sebagai agen mikroba dapat digunakan sebagai sebagai pakan pasta.

2. Mengetahui variasi kombinasi yang paling baik dari pengolahan limbah kulit jagung, dan limbah organik lainnya (dedak padi, abu sekam, batang pisang, pupuk kandang kambing) secara fermentasi untuk pembuatan pakan pasta.

\section{METODOLOGI PENELITIAN}

\section{Desain Penelitian}

Penelitian ini adalah pembuatan pakan semi padat dari campuran limbah kulit jagung, dedak padi, abu sekam, batang pisang, kotoran kambingmelalui fermentasi menggunakan probiotik ikan dan gula pasir.Penelitian yang akan dilakukan diawali dengan aktivasi probiotik ikan menggunakan air gula dan dilanjutkan denganpembuatan silase kulit jagung menggunakan probiotik ikan yang difermentasi selama 14 hari. Lalu dilanjutkan dengan pembuatan pakan semi padat dari campuran silase kulit jagung, dedak padi, abu sekam, batang pisang, pupuk kandang kambingmenggunakan probiotik ikanyang telah diaktifasi dan difermentasi selama 28 hari dengan 3 variasi komposisi. Analisis pakan semi padatdilakukan pada hari ke-0 (sebagai kontrol) dan hari ke-28 dengan parameter kadar air, kadar abu, kadar protein, kadar serat, kadar lemak dan kadar karbohidrat selanjutnya dilakukan analisis data.

\section{Tempat dan Waktu Penelitian}

Pelaksanaan penelitian ini akan dilaksanakan selama lebih kurang enam bulan, tempat penelitian dilaksanakan pada di Laboratorium Kimia FMIPA Universitas Muhammadiyah Riau dan di Laboratorium Makanan dan Minuman UPT Pengujian Dan Sertifikasi Mutu Barang Disdagkop UKM Provinsi Riau.

\section{Populasi dan Sampel}

Dalam penelitian ini yang menjadi populasi adalah bahan pakan fermentasi adalah kulit jagung, dedak padi, abu sekam, batang pisang, kotoran kambing dan probiotik ikan. Sedangkan sampel yang diambil diantaranya:

1. Kulit jagung didapat dari salah satu pasar di Pekanbaru

2. Dedak padi didapat dari salah satu toko penjualan pakan di Pekanbaru

3. Abu sekam didapat dari salah satu pasar di Pekanbaru

4. Batang pisang didapat dari batang pisang yang tumbuh di Pekanbaru

5. Kotoran kambing didapat dari salah satu peternakan di Pekanbaru

6. Probiotik ikandidapat dari salah satu toko penjualan pakan di Pekanbaru

\section{Alat dan Bahan}

Adapun peralatan yang digunakan dalam proses pembuatan pakan semi padat dari campuran silase kulit jagung, dedak padi, abu sekam, batang pisang, kotoran kambing menggunakan probiotik ikan diantaranya adalah sebagai berikut: bioreaktor, sarung tangan,masker, gunting, pisau. Alat yang digunakan untuk analisis pakan semi padat adalah neraca analitik, batang pengaduk, cawan petri, cawan porselen, gelas ukur, pipet tetes, pipet volume, erlenmeyer, beaker glass, oven,furnace, desikator, alat destilasi, alat soxhlet, water bath, buret.

Bahan-bahan yang digunakan dalam proses pembuatan pakan semi padat adalah: limbahkulit jagung, dedak padi, abu sekam, batang pisang, kotoran kambing, probiotik ikan, air suling, molase (gula pasir). Bahan yang digunakan dalam proses analisis pakan semi padat adalah campuran selen, larutan asam borat $\left(\mathrm{H}_{3} \mathrm{BO}_{3}\right) 2 \%$, 
larutan asam klorida $(\mathrm{HCl}) \quad 0,01 \mathrm{~N}$, larutan natrium hidroksida( $\mathrm{NaOH}) 30 \%$, larutan asam sulfat $\left(\mathrm{H}_{2} \mathrm{SO}_{4}\right) 1,25 \%$, etanol $96 \%$, petroleum benzen, larutan $\mathrm{Na}_{2} \mathrm{~S}_{2} \mathrm{O}_{3} 0,1 \mathrm{~N}$, larutan KI $20 \%$, larutan amilum 0,5\%, larutan $\mathrm{CH}_{3} \mathrm{COOH} 3 \%$, indikator PP, indikator metil orange, indikator campuran bromocresol green dan metil merah, kertas saring Whatman 41.

\section{Prosedur Pembuatan Pakan}

\section{Persiapan Bioreaktor}

Bioreaktor (wadah) yang digunakan berkapasitas 12 liter sebanyak 3 buah yang nantinya akan ditutup ketika melakukan proses fermentasi.

\section{Aktifasi Probiotik (Azhar, 2013)}

Probiotik yang masih dalam keadaan tidur (dormant) diaktifkan dengan memberikan makanan dan air. Pengaktifan dilakukan dengan menambahkan air dan air gula dengan perbandingan $300 \mathrm{~mL}$ probiotik +250 gr gula tebu $+1000 \mathrm{~mL}$ air. Kemudian difermentasi selama 14 hari pada suhu ruang.

\section{Pembuatan Silase Kulit Jagung (Pratiwi, 2015)}

Kulit buah jagung sebanyak $1,5 \mathrm{Kg}$ dibersihkan dengan air mengalir, dipotong kecilkecil sepanjang $1 \mathrm{~cm}$, dimasukkan kedalam bioreaktor. Molase $1 \mathrm{~L}$ yg sudah dicairkan (sudah dingin) dicampurkan dengan probiotik ikan sebanyak $300 \mathrm{~mL}$ dan diaduk sampai rata. Probiotik ikan yang telah diaktifasi dicampurkan ke potongan kulit jagung yang sudah ada di dalam wadah secara merata dan diaduk kembali. Campuran difermentasi dalam wadah yang tertutup rapat (secara anaerob) selama 14 hari.

Pembuatan pakan pasta atau semi padat (Munier, 2011)

Perlakuan pada penelitian ini adalah kombinasicampuran substrat fermentasi terdiri dari silase kulit jagung, kotoran kambing, dedak, batang pisang, abu sekam dan probiotik ikan pada tabel 1.

Tabel 1. Komposisi campuran pakan ikan

\begin{tabular}{|c|c|c|c|c|c|c|}
\hline Pakan & silase & kulit & batang & dedak & kotoran & abu sekam Probiotik \\
\hline & jagung & & pisang & & kambing & \\
\hline $\mathbf{A}$ & $140 \mathrm{~g}$ & & $175 \mathrm{~g}$ & $175 \mathrm{~g}$ & $157,5 \mathrm{~g}$ & $300 \mathrm{~mL}$ \\
\hline B & $210 \mathrm{~g}$ & & $140 \mathrm{~g}$ & $140 \mathrm{~g}$ & $157,5 \mathrm{~g}$ & $300 \mathrm{~mL}$ \\
\hline C & $280 \mathrm{~g}$ & & $105 \mathrm{~g}$ & $105 \mathrm{~g}$ & $157,5 \mathrm{~g}$ & $300 \mathrm{~mL}$ \\
\hline
\end{tabular}

Semua bahan diatas difermentasi selama 28 hari dan ditambahkan probiotik yang telah diaktifasi sebanyak $300 \mathrm{~mL}$ pada hari ke-7, 14 dan 21.

\section{Prosedur Analisis Proksimat Pakan}

Analisis proksimat yang dilakukan adalah analisis kadar abu, Kadar Air Total, Kadar Protein, Kadar Serat Kasar, kadar lemak, dan kadar karbohidrat. Metode analisa mengacu pada SNI-01-2891-1992.

\section{Uji Presisi}

Uji presisi dilakukan dengan menghitung hasil analisa menggunakan standar deviasi (SD) untuk menghasilkan relative standard deviation (RSD) atau coefisient variation (CV). Keseksamaan yang baik dinyatakan dengan semakin kecil persen RSD maka presisi semakin tinggi. Nilai standar deviasi, persen koefisien variasi dan persen koefisien variasi Horwitz dapat dihitung dengan mengikuti persamaan ekuivalen.

\section{Teknik Analisis Data}

Analisis data dalam penelitian ini berupa data kuantitatif yang disajikan dalam bentuk tabel. Data komposisi pakan semi padat dianalisis secara statistik menggunakan analisis keragaman Rancangan Acak Lengkap (RAL) dan perbedaan antara perlakuan diuji dengan uji Tukey. Model yang digunakan dalam rancangan acak lengkap yaitu:

Model linier: $\mathrm{Y}_{\mathrm{ijk}}=\mu+\tau \mathrm{i}+\varepsilon \mathrm{ij}$

Keterangan:

i : ulangan 1,2 
$\mathrm{Y}_{\mathrm{ijk}}$ : nilai pengamatan pada perlakuan ke-i dan ulangan ke-j

$\mu \quad$ : rataan umum

$\tau$ i : pengaruh perlakuan ke-i

eij : pengaruh acak pada perlakuan ke-i dan ulangan ke-j

$\mathrm{H}_{0}$ : jika variasi komposisi dan waktu fermentasi tidak berpengaruh nyata terhadap kadar air, abu, protein, lemak, serat dan karbohidrat

$\mathrm{H}_{1}$ : jika variasi komposisi dan waktu fermentasi berpengaruh nyata terhadap kadar air, abu, protein, lemak, serat dan karbohidrat.

\section{HASIL DAN PEMBAHASAN}

Hasil Penelitian

Pembuatan pakan ikan dari silase kulit jagung, dedak padi, abu sekam, batang pisang, kotoran kambing melalui fermentasi menggunakan probiotik ikan yang telah diaktivasi, dibuat dalam 3 (tiga) buah variasi komposisi dan pengukuran proksimat dilakukan pada fermentasi hari ke-0 dan hari ke-28. Pengujian proksimat yang diakukan pada penelitian ini adalah analisis kadar air, kadar abu, kadar protein, kadar lemak, kadar serat dan kadar karbohidrat. Data yang diperoleh dianalisis secara statistik menggunakan analisis keragaman Rancangan Acak Lengkap (RAL) dan perbedaan antara perlakuan diuji dengan uji Tukey.

Kadar air dari sampel pakan ikan fermentasi dianalisis menggunakan metode gravimetri. Hasil analisis kadar air sampel pakan ikan fermentasi dapat dilihat pada tabel 2.

Tabel 2. Hasil Analisis Kadar Air Pakan Ikan Fermentasi 0 dan 28 Hari

\begin{tabular}{ccccccc}
\hline \multirow{2}{*}{ Pakan } & \multicolumn{2}{c}{ Kadar Air (\%) } & \multicolumn{2}{c}{ \% RPD } & Syarat Mutu \\
& 0 Hari & 28 Hari & 0 Hari & 28 Hari & (\%) \\
\hline A & $65,32 \pm 0,03^{\mathrm{a}}$ & $78,02 \pm 0,03^{\mathrm{c}}$ & 0,06 & 0,05 & \\
B & $73,42 \pm 0,03^{\mathrm{b}}$ & $79,62 \pm 0,75^{\mathrm{e}}$ & 0,05 & 1,33 & 12 \\
C & $78,91 \pm 0,13^{\mathrm{d}}$ & $78,36 \pm 0,08^{\mathrm{c}}$ & 0,23 & 0,15 & \\
\hline
\end{tabular}

Keterangan : Angka-angka yang diikuti huruf yang berbeda menunjukkan perbedaan yang nyata $(\mathrm{P}<0,05)$

Pakan ikan dengan 3 variasi komposisi yang difermentasi selama 28 hari memberi pengaruh nyata terhadap nilai kadar air, $\mathrm{F}_{\text {hitung }}>\mathrm{F}_{\text {tabel }}$ (lampiran 4) pada taraf kepercayaan $95 \%$ maka $\mathrm{H}_{0}$ ditolak, untuk melihat perbedaan tersebut maka dilanjutkan dengan uji Tukey. Hasil uji Tukey menunjukkan bahwa nilai kadar airmasing-masing perlakuan berbeda nyata kecuali untuk perlakuan A28 dan C28.

Kadar abu dari sampel pakan ikan fermentasi dianalisis menggunakan metode gravimetri. Hasil analisis kadar abu sampel pakan ikan fermentasi dapat dilihat pada tabel 3 .

Tabel 3. Hasil Analisis Kadar Abu Pakan Ikan Fermentasi 0 dan 28 Hari

\begin{tabular}{cccccc}
\hline \multirow{2}{*}{ Pakan } & \multicolumn{2}{c}{ Kadar Abu (\%) } & \multicolumn{2}{c}{ \% RPD } & Syarat Mutu \\
& 0 Hari & 28 Hari & 0 Hari & 28 Hari & (\%) \\
\hline $\mathbf{A}$ & $7,31 \pm 0,03^{\mathrm{d}}$ & $10,37 \pm 0,04^{\mathrm{e}}$ & 0,55 & 0,58 & \\
$\mathbf{B}$ & $5,76 \pm 0,06^{\mathrm{c}}$ & $4,73 \pm 0,04^{\mathrm{a}}$ & 1,39 & 1,27 & 13 \\
$\mathbf{C}$ & $4,88 \pm 0,11^{\mathrm{b}}$ & $10,69 \pm 0,06^{\mathrm{f}}$ & 3,28 & 0,75 & \\
\hline
\end{tabular}

Keterangan: Angka-angka yang diikuti huruf yang berbeda menunjukkan perbedaan yang nyata $(\mathrm{P}<0,05)$

Pakan ikan dengan 3 variasi komposisi yang difermentasi selama 28 hari memberi pengaruh nyata terhadap nilai kadar abu, $\mathrm{F}_{\text {hitung }}>\mathrm{F}_{\text {tabel }}$ (lampiran 4) pada taraf kepercayaan 95\% maka $\mathrm{H}_{0}$ ditolak, untuk melihat perbedaan tersebut maka dilanjutkan dengan uji Tukey. Hasil uji
Tukey menunjukkan bahwa nilai kadar abu masing-masing perlakuan berbeda nyata.

Kadar protein dari sampel pakan ikan fermentasi dianalisis menggunakan metode semimikro kjeldhal. Hasil analisis kadar protein sampel pakan ikan fermentasi dapat dilihat pada tabel 4 
Tabel 4. Hasil Analisis Kadar Protein Pakan Ikan Fermentasi 0 dan 28 Hari

\begin{tabular}{|c|c|c|c|c|c|c|}
\hline \multirow[t]{2}{*}{ Pakan } & \multicolumn{2}{|c|}{ Kadar Protein (\%) } & \multicolumn{2}{|c|}{ \% RPD } & \multirow{2}{*}{\multicolumn{2}{|c|}{$\begin{array}{l}\text { Syarat } \\
(\%)\end{array}$}} \\
\hline & 0 Hari & 28 Hari & 0 Hari & 28 Hari & & \\
\hline$\overline{\mathbf{A}}$ & $3,63 \pm 0,07^{\mathrm{c}}$ & $4,79 \pm 0,02^{f}$ & 2,75 & 0,63 & & \\
\hline B & $2,68 \pm 0,03^{b}$ & $4,47 \pm 0,06^{\mathrm{e}}$ & 1,49 & 1,79 & $25-30$ & \\
\hline $\mathbf{C}$ & $2,56 \pm 0,03^{a}$ & $4,15 \pm 0,05^{\mathrm{d}}$ & 1,56 & 1,69 & & \\
\hline
\end{tabular}

Keterangan: Angka-angka yang diikuti huruf yang berbeda menunjukkan

perbedaan yang nyata $(\mathrm{P}<0,05)$

Pakan ikan dengan 3 variasi komposisi yang difermentasi selama 28 hari memberi pengaruh nyata terhadap nilai kadar protein, $F_{\text {hitung }}>F_{\text {tabel }}$ (lampiran 4) pada taraf kepercayaan 95\% maka $\mathrm{H}_{0}$ ditolak, untuk melihat perbedaan tersebut maka dilanjutkan dengan uji Tukey. Hasil uji Tukey menunjukkan bahwa nilai kadar protein masing-masing perlakuan berbeda nyata.
Kadar lemak dari sampel pakan ikan fermentasi dianalisis menggunakan metode ekstraksi soxhlet. Hasil analisis kadar lemak sampel pakan ikan fermentasi dapat dilihat pada tabel 5.

Tabel 5. Hasil Analisis Kadar Lemak Pakan Ikan Fermentasi 0 dan 28 Hari

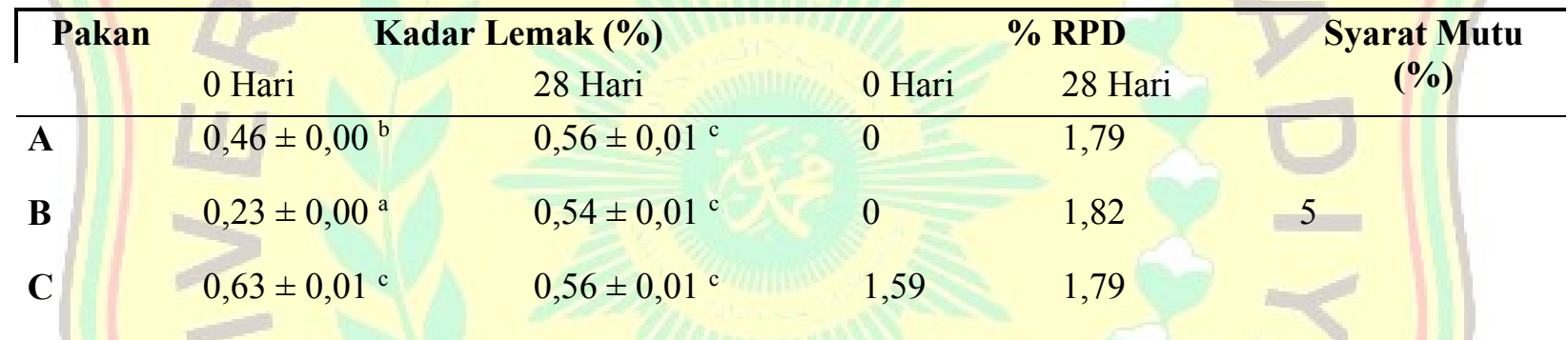

Keterangan: Angka-angka yang diikuti huruf yang berbeda menunjukkan

perbedaan yang nyata $(\mathrm{P}<0,05)$

Pakan ikan dengan 3 variasi komposisi yang difermentasi selama 28 hari memberi pengaruh nyata terhadap nilai kadar lemak, $F_{\text {hitung }}>F_{\text {tabel }}$ (lampiran 4) pada taraf kepercayaan 95\% maka $\mathrm{H}_{0}$ ditolak, untuk melihat perbedaan tersebut maka dilanjutkan dengan uji Tukey. Hasil uji Tukey menunjukkan bahwa nilai kadar lemak perlakuan $\mathrm{ABC} 0$ hari berbeda nyata dan perlakuan $\mathrm{ABC} 28$ hari tidak memiliki perbedaan yang nyata.

Kadar serat dari sampel pakan ikan fermentasi dianalisis menggunakan metode gravimetri. Hasil analisis kadar serat sampel pakan ikan fermentasi dapat dilihat pada tabel 6

Tabel 6. Hasil Analisis Kadar Serat Pakan Ikan Fermentasi 0 dan 28 Hari

\begin{tabular}{cccccc}
\hline \multirow{2}{*}{ Pakan } & \multicolumn{2}{c}{ Kadar Serat (\%) } & \multicolumn{2}{c}{ \% RPD } & Syarat Mutu \\
& 0 Hari & 28 Hari & 0 Hari & 28 Hari & (\%) \\
\hline A & $6,14 \pm 0,01^{\mathrm{f}}$ & $5,14 \pm 0,00^{\mathrm{e}}$ & 0,33 & 0 & \\
B & $4,97 \pm 0,00^{\mathrm{d}}$ & $4,04 \pm 0,01^{\mathrm{c}}$ & 0 & 0,25 & $6-8$ \\
C & $3,11 \pm 0,01^{\mathrm{b}}$ & $3,03 \pm 0,01^{\mathrm{a}}$ & 0,32 & 0,33 & \\
\hline
\end{tabular}

Keterangan: Angka-angka yang diikuti huruf yang berbeda menunjukkan perbedaan yang nyata $(\mathrm{P}<0,05)$ 
Pakan ikan dengan 3 variasi komposisi yang difermentasi selama 28 hari memberi pengaruh nyata terhadap nilai kadar serat, $F_{\text {hitung }}>F_{\text {tabel }}$ (lampiran 4) pada taraf kepercayaan 95\% maka $\mathrm{H}_{0}$ ditolak, untuk melihat perbedaan tersebut maka dilanjutkan dengan uji Tukey. Hasil uji
Tukey menunjukkan bahwa nilai kadar seratmasing-masing perlakuan berbeda nyata.

Kadar karbohidrat dari sampel pakan ikan fermentasi dianalisis menggunakan metode iodometri. Hasil analisis kadar karbohidrat sampel pakan ikan fermentasi dapat dilihat pada tabel 7.

Tabel 7. Hasil Analisis Kadar Karbohidrat Pakan Ikan Fermentasi 0 dan 28 Hari

\begin{tabular}{llllll}
\hline Pakan & \multicolumn{1}{l}{ Kadar Karbohidrat (\%) } & \% RPD & Syarat & Mutu \\
& 0 Hari & 28 Hari & 0 Hari & 28 Hari & (\%) \\
A & $5,70 \pm 0,11^{\mathrm{f}}$ & $3,83 \pm 0,00^{\mathrm{b}}$ & 2,81 & 0 & \\
B & $4,75 \pm 0,00^{\mathrm{d}}$ & $4,00 \pm 0,00^{\mathrm{c}}$ & 0 & 0 & \\
$\mathbf{C}$ & $5,11 \pm 0,06^{\mathrm{e}}$ & $3,30 \pm 0,00^{\mathrm{a}}$ & 1,76 & 0 & \\
\end{tabular}

Keterangan: Angka-angka yang diikuti huruf yang berbeda menunjukkan perbedaan yang nyata $(\mathrm{P}<0,05)$

Pakan ikan dengan 3 variasi komposisi yang difermentasi selama 28 hari memberi pengaruh nyata terhadap nilai kadar karbohidrat, $\mathrm{F}_{\text {hitung }}>$ $\mathrm{F}_{\text {tabel }}$ (lampiran 4) pada taraf kepercayaan $95 \%$ maka $\mathrm{H}_{0}$ ditolak, untuk melihat perbedaan tersebut maka dilanjutkan dengan uji Tukey. Hasil uji Tukey menunjukkan bahwa nilai kadar karbohidrat masing-masing perlakuan berbeda nyata.

\section{Pembahasan}

Pakanikan dibuat dari silase kulit jagung, dedak padi, abu sekam, batang pisang, pupuk kandang kambing dengan 3 variasi komposisi dan difermentasi selama 28 harimenggunakan probiotik ikan dan gula pasir. Kulit jagung memiliki kadar air 45-50\%, abu 3,89\%, bahan kering 42,56\%,protein kasar 3,4\%, Lemak kasar $2,55 \%$, serat kasar $23,318 \%$. Kotoran kambing dalam bentuk padat mengandung $\%$ unsur hara $\mathrm{N}$ $(0,60), \quad \mathrm{P} \quad(0,30), \quad \mathrm{K} \quad(0,17) \quad$ dan $60 \quad \%$ air.Kandungan nilai gizi dari batang pisang adalah bahan kering $87,70 \%$, bahan organik $62,68 \%$, abu $23,12 \%$, protein kasar $4,81 \%$, serat kasar 27,73\%, lemak kasar 14,23\%, Bahan Ekstrak Tanpa Nitrogen (BETN) 30,11\%, hemiselulosa $20,34 \%$, selulosa $26,64 \%$ dan lignin $9,92 \%$. Dedak padi halus dengan bahan keringnya mengandung abu $16,3 \%$, LK $3,7 \%$, SK 27,8\%, BETN 44,7\%, dan PK 7,6\%.sekam padi terdiri atas 50\% selulosa, $25-30 \%$ lignin, dan 15 - $20 \%$ silika. Bahan-bahan diatas digunakan sebagai campuran pakan fermentasi dengan 3 variasi komposisi. Analisis statistik menggunakan uji $\mathrm{F}$ dilakukan untuk melihat apakah variasi 3 komposisi mempengaruhi kadar air, abu, protein, lemak, serat dan karbohidrat pakan.

\section{Analisis Kadar Air}

Kadar air merupakan banyaknya air yang terkandung dalam bahan yang dinyatakan dalam persen. Metode yang digunakan untuk pengujian kadar air adalah metode oven. Prinsip dari metode oven adalah kehilangan bobot pada pemanasan $105^{\circ} \mathrm{C}$ dianggap sebagai kadar air yang terdapat pada contoh. Hasil analisis kadar air dapat dilihat pada Tabel 2. Analisisuji F menunjukkan perbedaan yang nyata $(\mathrm{P}<0,05)$ pada variasi 3 komposisi. Kadar air pakan A dan $\mathrm{B}$ yang dianalisis pada 0 dan 28 hari fermentasi mengalami peningkatan yaitu $(65,32 \pm 0,03 \%$ menjadi $78,02 \pm 0,03 \%)$ dan $(73,42 \pm 0,03 \%$ menjadi $79,62 \pm 0,75 \%$ ) sedangkan pakan $\mathrm{C}$ mengalami penurunan $(78,91 \pm 0,13 \%$ menjadi $78,36 \pm 0,08 \%$ ).

Peningkatan kadar air ini dikarenakan selamaproses fermentasi mikroorganisme menggunakan karbohidrat sebagai sumber energi yang dapat menghasilkan molekul air dan karbondioksida (Fardiaz, 1988). Sebagian besar air akan tertinggal dalam produk dan sebagian lagi akan keluar dari produk. Air yang tertinggal dalam produk inilah yang akanmenyebabkan kadar air menjadi tinggi danbahan kering menjadi 
rendah (Winarno et al., 1980). Penurunan kadar air pada pakan $\mathrm{C}$ kemungkinan disebabkan dosis probiotik yang digunakan pada pembuatan pakan ini masih sedikit, sehingga aktivitas mikroba yang berlangsung selama proses fermentasi tidak maksimal, atau campuran bahan pakan tidak homogen sehingga aktivitas dari mikroba tidak merata ke semua bagian pakan yang menyebabkan proses fermentasi tidak optimal.

\section{Analisis Kadar Abu}

Abu merupakan zat anorganik sisa hasil pembakaran suatu bahan organik. Metode yang digunakan untuk pengujian kadar abu adalah metode gravimetri. Prinsip dari metode gravimetri adalah pengabuan bahan organik untuk meninggalkan residu anorganik sebagai abu.Hasil analisis kadar abu dapat dilihat pada Tabel 3. Analisis uji $\mathrm{F}$ menunjukkan perbedaan yang nyata $(\mathrm{P}<0,05)$ pada variasi 3 komposisi. Kadar abu pakan B yang dianalisis pada 0 dan 28 hari fermentasi mengalami penurunan yaitu $(5,76$ $\pm 0,06 \%$ menjadi $4,73 \pm 0,04 \%$ ) sedangkan pakan A dan $\mathrm{C}$ mengalami peningkatan yaitu $(7,31 \pm$ $0,03 \%$ menjadi $10,37 \pm 0,04 \%)$ dan $(4,88 \pm$ $0,11 \%$ menjadi $10,69 \pm 0,06 \%$ ).

Penentuan kadar abu dimaksudkan untuk mengetahui kandungan komponen yang tidak mudah menguap (komponen anorganik atau garam mineral) yang tetap tinggal pada pembakaran dan pemijaran senyawa organik (Nurilmala, 2006). Penurunan kadar abu ini dipengaruhi oleh penggunaan mineral untuk mempertahankan hidup mikroorganisme. Karena mikroorganisme membutuhkan mineral untuk mempertahankan hidupnya meskipun dalam jumlah yang sedikit (Fardiaz, 1992). Kadar serat kasar dan kadar abu memiliki hubungan yang positif, tingginya serat kasar akan berpengaruh positif terhadap tingginya kadar abu pada suatu bahan (Wibowo, 2010). Semakin lama fermentasi, kadar abuakan meningkat karena proses fermentasi akan meningkatkan kandungan asam-asam organik seperti asam asetat, malat, oksalat, dan lain-lain. Jika kandungan asam-asam organik meningkat, kandungan garam dalam asam-asam organik tersebut juga akan meningkat sehingga akan menyebabkan meningkatnya kadar abu dalampakan. Mineral yang terdapat dalam suatu bahan terdiri dari dua macam garam, yaitu garamorganik (garam dari asam malat, oksalat, asetat, dan lain-lain) dan garam anorganik (fosfat, karbonat, klorida, sulfat nitrat, dan logam alkali) (Ciptaningsih, 2012).

\section{Analisis Kadar Protein}

Protein merupakan sumber asam amino yang terdiri dari unsur $\mathrm{C}, \mathrm{H}, \mathrm{O}$, dan N.Metode yang digunakan untuk pengujian kadar protein adalah metode semimikro kjeldhal. Prinsip dari metode semimikro kjeldhal yaitu senyawa nitrogen diubah menjadi ammonium sulfat oleh $\mathrm{H}_{2} \mathrm{SO}_{4}$ pekat. Kemudian ammonium sulfat yang terbentuk diuraikan dengan $\mathrm{NaOH}$ dan ammonium yang dibebaskan diikat dengan asam borat, kemudian dititar dengan larutan baku asam. Hasil analisis kadar protein dapat dilihat pada Tabel 4.4. Analisis uji $\mathrm{F}$ menunjukkan perbedaan yang nyata $(\mathrm{P}<0,05)$ pada variasi 3 komposisi.Kadar protein pakanyang dianalisis pada 0 dan 28 hari fermentasi mengalami peningkatan. Pakan A $(3,63 \pm 0,07 \%$ menjadi $4,79 \pm 0,02 \%)$, pakan $\mathrm{B}(2,68 \pm 0,03 \%$ menjadi $4,47 \pm 0,06 \%)$ dan pakan C $(2,56 \pm 0,03 \%$ menjadi $4,15 \pm 0,05 \%$ ).

Protein yang meningkat selama proses fermentasi dikarenakan adanya pengayaan protein dari selmikroorganisme. Proses peningkatan kandungan protein karena adanya pembentukan single cell proteinatau protein sel tunggal (Litchfield, 1983). Selama proses fermentasi mikroba akan mengeluarkan enzim, dimana enzim tersebut adalahprotein dan mikroba itu sendiri juga merupakan sumber protein sel tunggal (Fardiaz, 1987). Ketika proses fermentasi selesai antara sel yang tumbuh dengan sisa substratnya tidakdipisahkan atau disebut dengan Microbial Biomass Product (MBP) sehingga protein akan terakumulasi dan terjadi peningkatan kandungan protein (Muhiddin et al., 2001).

Selain itu meningkatnya kandungan protein selama proses fermentasi karena glukosa akan diubah menjadi asam piruvat melalui jalur glikolisis kemudian dari proses glikolisis akan terbentuk senyawa-senyawa intermediet yang selanjutnya melalui proses aminasi maupun transaminasi dapat menghasilkan asam-asam 
amino. Terbentuk empat jenis asam amino, yaitu serin dibentuk dari sintesis 3 -fosfo gliserat, serin akan menghasilkan glisin dan sistein serta alanin yang terbentuk dari asam piruvat yang merupakan produk dari proses glikolisis (Mark et al., 1996).

\section{Analisis Kadar Lemak}

Lemak dibutuhkan sebagai sumber asamasam lemak esensial dan sebagai sumber energi. Metode yang digunakan untuk pengujian kadar lemak adalah metode ekstraksi soxhlet. Prinsip dari metode ekstraksi soxhlet yaitu ekstraksi lemak bebas dngan pelarut nonpolar. Hasil analisis kadar lemak dapat dilihat pada Tabel 5. Analisis uji $\mathrm{F}$ menunjukkan perbedaan yang nyata $(\mathrm{P}<0,05)$ pada variasi 3 komposisi. Kadar lemak pakan $\mathrm{C}$ yang dianalisis pada 0 dan 28 hari fermentasi mengalami penurunan yaitu $(0,63 \pm$ $0,01 \%$ menjadi $0,56 \pm 0,01 \%$ ) sedangkan pakan A dan B mengalami peningkatan yaitu $(0,46 \pm$ $0,00 \%$ menjadi $0,56 \pm 0,01 \%)$ dan $(0,23 \pm 0,00 \%$ menjadi $0,54 \pm 0,01 \%$ ).

Kadar lemak pakanA dan Bmengalami peningkatan, diduga karena adanya asam lemak yang dihasilkan pada penambahan starter dan bahan pakan (batang pisang). Selama proses fermentasi silase, terdapat aktivitas bakteri yang menghasilkan asam lemak cukup tinggi sehingga kandungan lemak cenderung meningkat. Lemak tidak dengan mudah digunakan karena mikroba lebih cenderung memanfaatkan karbohidrat dan protein terlebih dahulu. Enzim yang pertama kali aktif dalam fermentasi adalah amilase yang mulai bekerja pada 12 jam pertama, kemudian pada rentang waktu 12-24 jam aktivitas enzim protease mulai maksimal dan pada enzim lipase baru bekerjamaksimal pada rentang waktu 24-36 jam (Karmani, et al., 1996).

Analisis uji $\mathrm{F}$ menunjukkan tidak ada perbedaan nyata pada pakan $\mathrm{C}$ fermentasi 0 dan 28 hari, diduga karena bakteri masih menggunakan karbohidrat sebagai sumber energi sehingga tidak terjadi pemecahan trigliserida oleh bakteri.

\section{Analisis Kadar Serat}

Serat kasar merupakan fraksi dari karbohidrat yang tidak larut dalam basa dan asam setelah pendidihan masing-masing 30 menit. Metode yang digunakan untuk pengujian kadar serat adalah metode gravimetri. Prinsip dari metode gravimetri yaitu zat organik yang tidak dapat larut basa dan asam setelah pendidihan masingmasing 30 menit (residu) dibakar sesuai prosedur analisis abu, maka selisih antara residu dengan abu adalah serat kasar.Hasil analisis kadar seratdapat dilihat pada Tabel 4.6. Analisis uji $\mathrm{F}$ menunjukkan perbedaan yang nyata $(\mathrm{P}<0,05)$ pada variasi 3 komposisi.Kadar serat pakan yang dianalisis pada 0 dan 28 hari fermentasi mengalami penurunan. Pakan A $(6,14 \pm 0,01 \%$ menjadi $5,14 \pm 0,00 \%)$, pakan $\mathrm{B}(4,97 \pm 0,00 \%$ menjadi $4,04 \pm 0,01 \%)$, pakan C $(3,11 \pm 0,01 \%$ menjadi $3,03 \pm 0,01 \%$ ).

Serat kasar adalah bagian dari bahanpakan yang terdiri dari selulosa, hemiselulosa, lignin dan polisakarida lain yang berfungsi sebagai bagian pelindung (Anggorodi, 1994). Penambahan bakteri asam laktat mampu menurunkan kandungan serat kasar selamafermentasi. Mikroba selulolitik menggunakan selulosa sebagai sumber energi dan karbon dengan cara menghasilkan enzim selulase yang dapat merombak dan mendegradasi komponen selulosa dan turunannya yang panjang menjadi glukosa. Glukosa yang diperoleh akandigunakan untuk menghasilkan energi (ATP), alkohol dan karbondioksida Akibatnya produk akhir yang dihasilkan lebih mudah dicerna jika dibandingkan dengan bahan tanpa fermentasi (Indriawan, 2014).

\section{Analisis Kadar Karbohidrat}

BETN merupakan karbohidrat yang dapat larut meliputimonosakarida, disakarida dan polisakarida yang mudah larut dalam larutan asam dan basa serta memiliki daya cerna yang tinggi (Anggorodi, 1994). Metode yang digunakan untuk pengujian kadar karbohidrat adalah metode Iodometri. Prinsip dari metode Iodometri yaitu hidrolisis karbohidrat menjadi monosakarida yang dapat mereduksikan $\mathrm{Cu}^{+2}$ menjadi $\mathrm{Cu}^{+1}$. Kelebihan $\mathrm{Cu}^{+2}$ dapat dititar secara Iodometri. Hasil analisis kadar karbohidrat dapat dilihat pada Tabel 4.7. Analisis uji F menunjukkan perbedaan yang nyata $(\mathrm{P}<0,05)$ pada variasi 3 komposisi.Kadar karbohidrat pakan yang dianalisis pada 0 dan 28 hari 
fermentasi mengalami penurunan. Pakan A $(5,70$ $\pm 0,11 \%$ menjadi $3,83 \pm 0,00 \%)$, pakan $\mathrm{B}(4,75 \pm$ $0,00 \%$ menjadi $4,00 \pm 0,00 \%)$ dan pakan $\mathrm{C}(5,11$ $\pm 0,06 \%$ menjadi $3,30 \pm 0,00 \%$ ).

Fermentasi merupakan aktivitas perombakan karbohidrat oleh mikroorganisme menjadi alkohol, asam organik, air dan karbondioksida (Wilkinson, 1998). Enzim amilase berperan dalam mengubah pati menjadi glukosa dengan memutuskan ikatan glukosida yaitu ikatan antara molekul glukosa pada polimer pati. Hasil pemecahan glukosa oleh enzim amilase akan digunakan untuk proses metabolisme. Proses metabolisme dimulai dengan mengolah glukosa menjadi asam piruvat karena proses metabolisme terjadi secara anaerob (fermentasi), maka asam piruvat yang terbentuk akan diubah menjadi produk fermentasi yaitu ATP (Adenosin Tri Phosphate) yang digunakan sebagai sumber energi untuk tumbuh dan berkembang, kemudian hasil lainnya adalah alkohol dan $\mathrm{CO}_{2}$ sebagai hasilmetabolisme (Hawusiwa,et al., 2015).

\section{KESIMPULAN}

Berdasarkan hasil penelitian yang dilakukan dapat disimpulkan bahwa:

1. Variasi komposisi dan waktu fermentasi berpengaruh nyata terhadap kadar air,abu, protein, lemak, serat dan karbohidrat.

2. Pakan dengan variasi komposisi $\mathrm{C}$ yaitu $\mathbf{2 8 0}$ $\mathrm{g}$ silase kulit jagung, $105 \mathrm{~g}$ batang pisang, dedak 105 g, kotoran kambing 157,5 g, abu sekam 17,5 g, probiotik ikan yang telah diaktifasi $300 \mathrm{~mL}$ merupakan komposisi terbaik dengan kadar air 78,36 $\pm 78,36 \%$, kadar abu $10,69 \pm 0,06 \%$, kadar protein 4,15 $\pm 0,05 \%$, kadar lemak $0,56 \pm 0,01 \%$, kadar serat $3,03 \pm 0,01 \%$ dan kadar karbohidrat $3,30 \pm 0,00 \%$.

\section{DAFTAR PUSTAKA}

Ahmadi, H., Iskandar., Kurniawati, N., 2012. Pemberian Probiotik Dalam Pakan Terhadap Pertumbuhan Lele Sangkuriang (Clarias graprienus) Pada Pendederan II. Jurnal, Vol. 3(4): 99-107 Anggorodi, R. 1994. Ilmu Makanan Ternak Umum. Gramedia Pustaka Utama. Jakarta.
Anggraeny, Y.N., Umiyasih, U. dan Pamungkas, D. 2005.Pengaruh suplementasi multinutrien terhadap performan sapi potong yang memperolehpakan jerami jagung.Pros. Seminar Nasional Teknologi Peternakan dan Veteriner.147-152.

Anggraeny, Y.N., Umiyasih, U. dan Krishna, N.H. 2006. Potensi limbah jagung siap rilis sebagai sumber hijauan sapi potong. Pros. Lokakarya Nasional JejaringPengembangan Sistem Integrasi Jagung-Sapi. 149-153.

Arief, M., Fitriani, N., Subekti, S. 2014.Pengaruh Pemberian Probiotik Berbeda Pada Pakan Komersial Terhadap Pertumbuhan dan Efisiensi Pakan Ikan Lele Sangkuriang (Clarias sp.). Jurnal Ilmiah Perikanan dan Kelautan Vol. 6(1): 49-53

Azhar, F. 2013. Pengaruh Pemberian Probiotik dan Prebiotik Terhadap Performan Juvenile Ikan Kerapu Bebek (Comileptes altivelis). Buletin Veteriner Udayana, Vol. 6(1): 1-9.

Bandar Standirisasi Nasional. 1992. Cara Uji Makanan dan Minuman. SNI-01-28911992.

Ciptaningsih, E. 2012.Uji Aktivitas Antioksidan dan Karakteristik Fitokimia pada Kopi LuwakArabika dan Pengaruhnya terhadap Tekanan Darah Tikus Normal dan Tikus Hipertensi. Tesis. Universitas Indonesia.

Devani, V dan Basriati, S. 2015. Optimasi Kandungan Nutrisi Pakan Ikan Buatan dengan Menggunakan Multi Objective (Goal)Programming Model. Jurnal Sains, Teknologi dan Industri, Vol. 12(2): 255261

Faharuddin. 2014. Analisis Kandungan Bahan Kering, Bahan Organik dan Protein Kasar Silase Pucuk Tebu (Saccharum officinarum L.) yang Difermentasi Dengan Urea, Molases dan Kalsium Karbonat. Skripsi. Fakultas Peternakan, Universitas Hasanuddin, Makassar

Fardiaz, S.1992. Mikrobiologi Pangan I. Gramedia Pustaka Utama, Jakarta.

Hawusiwa, E.S., Wardani, A.K. \& Ningtyas, D.W. 2015. Pengaruh Konsentrasi 
Pasta Singkong (Manihot esculenta) Dan

Lama Fermentasi Pada Proses Pembuatan Minuman Wine Singkong. Jurnal Pangan dan Agroindustri (3): 147155.

Indriawan, A. 2014. Pengaruh Suhu Terhadap AktivitasSelulase Isolat Bakteri Usus Itik (Anas Domestica) Sebagai Kandidat Probiotik. Skripsi. Universitas Lampung, Lampung.

Karmani, M., Sutopo, D. \& Hermana, H. 1996.AktivitasEnzim Hidrolik Kapang Rhizopus Sp. Pada Proses Fermentasi Tempe.Jurnal Penelitian Gizi dan Makanan (19): 93-102.

ark, D.B., Mark,D.A.\& Smith, M.C. 1996. Biokimia Kedokteran Dasar. EGC,Jakarta.

Muhiddin, N.H., Juli, N. \& Aryantha, I.N.P. 2001.Peningkatan Kandungan Protein Kulit Umbi Ubi Kayu Melalui Proses Fermentasi. JMS(6):1-12.

Mulijanti, S.L., Tedy, S., Nurnayetti. 2014. Pemanfaatan Dedak Padi dan Jerami Fermentasi pada Usaha Penggemukan Sapi Potong di Jawa Barat. Jurnal Peternakan Indonesia, Vol. 16(3): 179187

Munier, F.F. 2011. Evaluasi Karakteristik Silase Campuran Kulit Jagung dan Daun Lamtoro (Leucaena leucochepala) Tanpa dan Dengan Molases. Seminar Nasional Teknologi Peternakan dan Veteriner, 515 521

Pratiwi, I., Fathul, F. dan Muhtarudin. 2015. Pengaruh Penambahan Berbagai Starter
Pada Pembuatan SilaseRansum Terhadap Kadar Serat Kasar, Lemak Kasar, Kadar Air, dan Bahan Ekstrak Tanpa Nitrogen

Silase. Jurnal Ilmiah Peternakan Terpadu,Vol. 3(3): 116-120

Putra, A. N. 2010. Kajian Probiotik, Prebiotik dan Sinbiotik Untuk Meningkatkan Kinerja Pertumbuhan Ikan Nila (Oreochromis niloticus). Tesis. Program Pasca Sarjana. Institut Pertanian Bogor. Bogor.

Santi, N.P.A.A., Bidura, I.G.N.G., Candrawati, D.P.M.A. 2015. Kecernaan dan Nilai Nutrisi Dedak Padi Yang Difermentasi Dengan Saccharomyces sp.Isolat Dari Ragi Tape. Journal of Tropical Animal Science, Vol. 3(1): $\quad$ 146-160

Setiawati, J.E., Tarsim, Adipura, Y.T., Hudaibah, S. 2013. Pengaruh Penambahan Probiotik Pada Pakan Dengan Dosis Berbeda Terhadap Pertumbuhan, Kelulushidupan, Efisiensi Pakan dan Retensi Protein Ikan Patin (Pangasius hypophthalmus). eJurnal Rekayasa dan Teknologi Budidaya Perairan, Vol. 1(2): 151-162

Wibowo, A.H. 2010. Pendugaan Kandungan NutrienDedak Padi Berdasarkan Karakteristik Fisik.Tesis. Bogor: Institut Pertanian Bogor.

Wilkinson. J. M. 1988. The Feed Value of By Product and Wastes In Feed. Science. Scotland.

Winarno, F.G., Fardiaz, S. dan Fardiaz, D. 1980. Pengantar Teknologi Pangan. PT Gramedia, Jakarta. 